\title{
Anatomical, Physical, and Mechanical Properties of Thirteen Malaysian Bamboo species
}

\author{
Nordahlia Abdullah Siam,* Mohd Khairun Anwar Uyup, Hamdan Husain, \\ Abd Latif Mohmod, and Mohd Fahmi Awalludin
}

The anatomical, physical, and mechanical properties of 13 Malaysian bamboos and the trend of these properties along the bamboo culms' height were examined. The results showed that these properties varied between the 13 species and they were also affected by the culm height. From the results obtained, the fibre morphology, as well as radial, longitudinal, and tangential shrinkage from green to oven-dry decreased from the basal to the top of the bamboo culm. In contrast, the opposite trend was observed for the density, modulus of rupture, modulus of elasticity, and percentage of the vascular bundle. The potential usage of 13 bamboo species is also considered.

Keywords: Anatomical properties; Physical properties; Strength properties; Malaysian bamboo

Contact information: Forest Research Institute Malaysia, 52109 Kepong, Selangor, Malaysia;

*Corresponding author: nordahlia@frim.gov.my

\section{INTRODUCTION}

Bamboo is considered a fast-growing plant that is widely used for the manufacture of handicrafts, baskets, furniture, and general merchandise. The use of bamboo has evolved from traditional to more value-added products. According to Xing et al. (2015), bamboo can be regarded as the best alternative for replacing timber because bamboo has high strength and is fast-growing. As stated by Krause and Ghavami (2009), bamboo in its round form demonstrates excellent mechanical properties that make it useful for the construction industry and can reduce the need for steel. Bamboo is a cylindrical, usually hollow, light-weight, and functionally-graded material that demonstrates optimal characteristics for building truss elements that are frequently used in civil construction. In addition, Xing et al. (2015) reported that bamboo is an important raw material for housing and bridge construction in China. Bamboo has also been used in a wide range of engineering and civil construction applications including scaffolding, fiber-reinforced composites, and bridges (Tan et al. 2011). Because the uses of bamboo have become more diversified, it is important to understand the basic anatomical, physical, and mechanical properties of the particular bamboo to assess its suitability for the intended purposes. According to Abd. Latif et al. (1990), Razak et al. (2002, 2005, and 2010), and Wang et al. (2016), the anatomical properties of bamboo are important due to their effect on mechanical properties, preservative absorption, and properties of the end products, especially pulp and paper. Anatomical properties can also influence the bamboo's durability, toughness, workability, and strength (Liese 1985; Espiloy 1987; Razak et al. 2010). These findings were further supported with a study by Xin et al. (2015), where it was concluded that the anatomical structure of bamboo is basic knowledge for understanding the physical and mechanical properties as well as the utilizations of the bamboo.

Density and shrinkage are considered important factors for determining the suitability of bamboo for various applications, with density being associated with the 
mechanical properties (Anwar et al. 2005a; Abdullah et al. 2017). Determination of the mechanical properties of bamboo is important to fully understand its behaviour and performance in structural design and industrial use (Shahril and Mansur 2009; Correal and Arbelaez 2010; Gutu 2013).

There are at least 63 species of bamboo in Peninsular Malaysia. Of them, 25 are indigenous, while the rest are known only in cultivation (Abd. Razak and Abd. Latif 1995). From this total number of species, only 13 species are known to be commercially utilized, including Bambusa blumeana (buluh duri), B. vulgaris (buluh aur/minyak), $B$. heterostachya (buluh galah), Gigantochloa scortechinii (buluh semantan), G. thoii (buluh beting), G. ligulata (buluh tumpat), G. wrayi (buluh beti), and Schizostachyum brachycladum (buluh lemang) (Abd. Razak and Abd. Latif 1995). From these 13 species, $B$. vulgaris and $G$. scortechinii were reported as suitable for making particleboard, laminated bamboo boards, ply bamboo, and bamwood (Razak et al. 1997; Jamaluddin et al. 1999; Zaidon et al. 2004; Anwar et al. 2004, 2005b; Hanim et al. 2010; Anwar et al. 2011, 2012). An intensive study on bamboo properties should be conducted for all 13 bamboo species to assess each species' suitability for end products. Therefore, the objective of this study is to determine the anatomical, physical, and mechanical properties of the 13 species. The trends of these properties along the bamboo culm height were also examined. Based on the derived properties it will be used to determine the bamboo species for suitable end products.

\section{EXPERIMENTAL}

\section{Materials}

Field sampling

Thirteen species of Malaysian bamboo, Gigantochloa thoii, G. scortechinii, G. ligulata, G. wrayi, G. brang, Schizostachyum brachycladum, S. grande, S. zollingeri, Bambusa vulgaris, B. blumeana, B. heterostachya, B. vulgaris $c v$ Vittata, and Dendrocalamus asper, were obtained from the bamboo plantation research plot, Forest Research Institute Malaysia (FRIM) campus (Kepong, Selangor, Malaysia). Five culms from each species were selected and harvested. Four-year-old bamboos were chosen in this study due to their level of maturity. Sattar et al. (1992) illustrated that bamboo culms start maturing at the age of three years. This age was determined by observing a tag that was placed on the culm during the shoot's sprouting stage. The bamboo culms were cut at approximately $20 \mathrm{~cm}$ above the ground level. Each culm was cut to a length of $12 \mathrm{~m}$ and was later subdivided into three equal lengths corresponding to the basal, middle, and top portions. The bamboo culms were split into eight sections using a splitting machine. For assessment on the anatomical, physical, and mechanical properties, split samples were tested at $12 \%$ moisture content. A split is a bamboo sample with the periphery and inner skin remaining intact.

\section{Methods}

\section{Determination of the anatomical properties of bamboo}

The anatomical studies on the types of vascular bundles and their distributions were conducted according to the method outlined by Abd. Latif and Mohd. Tamizi (1992). Bamboo sample blocks were cut into sections of $10 \mathrm{~mm} \times 10 \mathrm{~mm} \times$ culm wall thickness. The blocks were boiled in distilled water until the bamboo samples softened. Then, $25-\mu \mathrm{m}$ thick sections were cut using a sledge microtome (Reichert, Vienna, Austria). Each section was stained with aqueous safranin-O (Sigma, New Delhi, India). These sections were 
washed with $50 \%$ ethanol and dehydrated using a series of ethanol solutions with concentrations of 70\%, 80\%, 90\%, and 95\% (Merck, Selangor, Malaysia). Then, one drop of Canada Balsam (Merck, Darmsladt, Germany) was placed on top of the section and covered with a cover slip. The slides were oven-dried at $60{ }^{\circ} \mathrm{C}$ for a few days.

The maceration technique was used to determine the fibre morphology. Bamboo splits $(20 \mathrm{~mm} \times 10 \mathrm{~mm} \times$ culm wall thickness) were chipped into the size of a matchstick. Then, they were macerated using a mixture of $30 \%$ hydrogen peroxide:glacial acetic acid (1:1 ratio) at $45^{\circ} \mathrm{C}$ (Wheeler et al. 1989; Abasolo et al. 2005) for 2 to $3 \mathrm{~h}$ until all of the lignin had dissolved and the cellulose fibres appeared whitish. The macerating solution was then carefully washed in distilled water until all traces of the acid disappeared. Then, the cellulose fibres were kept in the vials. The vials were then gently agitated to ensure sufficient separation of cellulose fibres. The vials were then half-filled with distilled water and securely capped. The macerated fibres were spread out on a glass slide, drops of safranin-O were added, and a cover slip was applied.

Quantitative measurements of the fibre length, diameter, wall thickness, and lumen diameter were made from the slides using an optical microscope (Olympus Corporation, Tokyo, Japan). The distributions of vascular bundles were determined by counting the number of vascular bundles per $\mathrm{mm}^{2}$ on a cross-section. The fibre wall thickness was obtained by subtracting the value of fibre lumen diameter from fibre diameter and dividing by two. The aspect ratio (fibre length / fibre diameter) and Runkel ratio $(2 \times$ wall thickness / lumen diameter) (Singh and Mohanty 2007; Gülsoy et al. 2017) were also calculated.

\section{Determination of some physical and mechanical properties}

Physical properties of bamboo splits were tested using methods from the Indian Standards Institution (Anonymous 1976). Samples $(20 \mathrm{~mm} \times 20 \mathrm{~mm} \times$ culm wall thickness) were obtained from the basal, middle, and top portions for analysis of density and shrinkage from green to oven-dry. A total of 1,560 specimens were used in the study.

The radial, longitudinal, and tangential sections of each sample were marked and measured with digital vernier calipers to the nearest $0.01 \mathrm{~mm}$. All samples were placed in an oven dried and maintained at $103 \pm 2{ }^{\circ} \mathrm{C}$ for $48 \mathrm{~h}$ and the shrinkage test was conducted during progress from green to oven-dry conditions. Shrinkage $\left(S_{\mathrm{o}}\right)$ was calculated according to Eq. 1,

$$
S_{o}(\%)=\left(\frac{D_{i}-D_{o}}{D_{i}}\right) \times 100
$$

where $S_{\mathrm{o}}$ is the shrinkage (\%) from green to oven-dry conditions, $D_{\mathrm{i}}$ is the initial dimension length $(\mathrm{mm})$, and $D_{\mathrm{o}}$ is the oven-dry dimension length ( $\left.\mathrm{mm}\right)$.

For the modulus of rupture (MOR) and modulus of elasticity (MOE), the split samples of $300 \mathrm{~mm} \times 20 \mathrm{~mm}$ were obtained from the basal, middle, and top portions were air-dried in the shade for about one month and then conditioned for two weeks in a conditioning room at $65 \%$ relative humidity and $20{ }^{\circ} \mathrm{C}$. A total of 60 specimens were prepared for this study. A $100 \mathrm{KN}$ Shimadzu testing machine (Kyoto, Japan) was used and testing was performed with central loading and a cross-head speed of $0.65 \mathrm{~mm} / \mathrm{s}$ with two supports over a span of $140 \mathrm{~mm}$. The samples were tested in accordance to the procedure described by Gnanaharan et al. (1994).

\section{Statistical analysis}

Statistical analysis was performed using Statistical Analysis System (SAS) version 9.1.3 software (SAS Institute, Cary, NC). A one-way analysis of variance (ANOVA) was 
conducted to determine whether the differences in means were significant. If the differences were significant, the least significant difference (LSD) test was used to determine which of the means were significantly different from one another.

\section{RESULTS AND DISCUSSION}

\section{Physical Characteristics}

The identification of a bamboo species at the field usually begins by looking at its physical characteristics. Information gathered on the physical characteristics is important, as it quickens the identification of bamboo specimens that have an absolute characteristic distinction between species such as its culm height, internode length, and culm wall thickness. Based on the physical characteristics of bamboo species such as culm wall thickness, internode, and culm length, it can also be used to determine the suitable end products.

The physical characteristics of the 13 respective bamboo species in this study are presented in Table 1. The highest culm height at $32 \mathrm{~m}$ was recorded from $S$. grande, followed by $B$. vulgaris $c$ v vittata $(30 \mathrm{~m})$, and $S$. zollingeri $(22 \mathrm{~m})$. The $S$. grande species had the longest internode length at $65 \mathrm{~cm}$, followed by $S$. zollingeri $(55 \mathrm{~cm})$, and $S$. brachycladum $(53 \mathrm{~cm})$. The shortest internode length was measured from the $B$. blumeana species at $32 \mathrm{~cm}$. The highest value of culm wall thickness was obtained from $D$. asper $(16 \mathrm{~mm})$, followed by $G$. brang $(14 \mathrm{~mm})$. The lowest culm wall thickness value was recorded from the $S$. zollingeri species at $4 \mathrm{~mm}$.

From the result obtained, Dendrocalamus asper, Gigantochloa, and Bambusa have the thickest culm wall compared to Schizostachyum. On the other hand, Schizostachyum can be characterised by its longest internode and thinnest culm wall. Most Bambusa have shorter internode (except for B. heterostachya) as compared to other bamboo species. Based on the physical properties, species from the genus Schizostachyum is suitable for crafts, satay sticks, basketry, toothpick, water container and other general utility. This species is also use as vessels for cooking glutinous rice, called lemang. While, D. asper, Bambusa and Gigantochloa having the thickest culm wall makes it suitable for parquet, furniture and building structures.

\section{Anatomical Properties}

Liese (1998) described the four basic types of vascular bundles, which are vascular bundle types I, II, III, and IV. Type I vascular bundles are usually present in monopodial species of bamboos, whilst vascular bundles of type II, III, and IV are present in sympodial species of bamboos. Figure 1 shows anatomical structures of the 13 species studied. The vascular bundle type of Malaysian bamboo are classified as the following:

Type II: S. brachycladum and S. zollingeri with enlarged fibre sheath at the phloem side. Type III: $G$. thoii, G. scortechinii, G. ligulata, G. wrayii, G. brang, S. grande, B. heterostachya, and $B$. vulgaris $c v$. vittata with one isolated fibre bundle.

Type IV: $B$. vulgaris, $B$. blumeana, and $D$. asper with a central vascular strand that has small sclerenchyma sheaths, and two isolated fibre strands located at the phloem and protoxylem sides.

The result obtained in this present study is similar with observation made by Grosser and Liese (1971). They also concluded that type IV vascular bundle is related to the thick walled internodes of large size bamboos as found in this study in B. vulgaris, $B$. blumeana, and D. asper. 

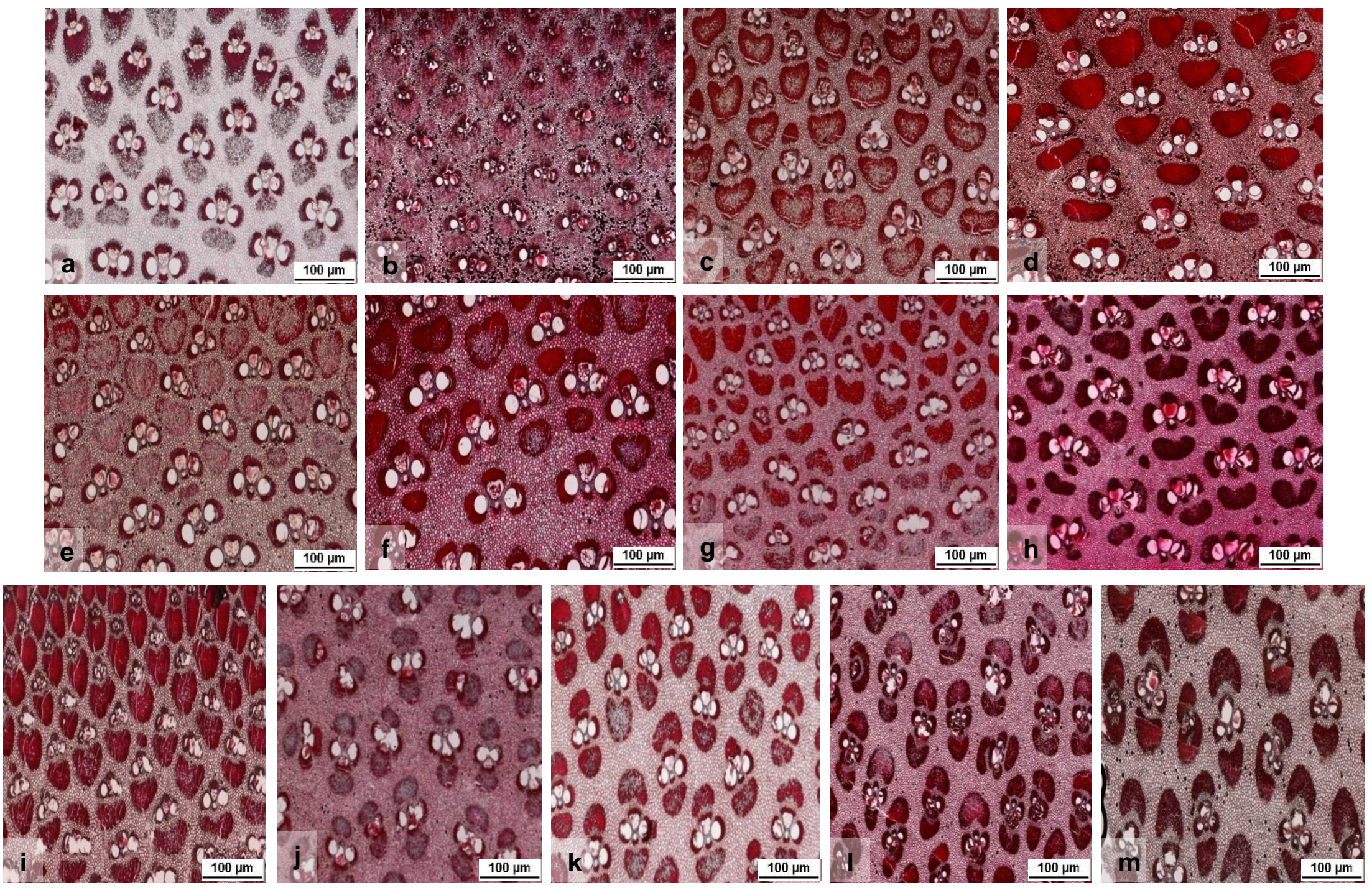

Fig. 1. Type of vascular bundle: a) and b) type II vascular bundle: S.brachycladum and $S$. zollingeri, respectively; c through j) type III vascular bundle: G. thoii, G. scortechinii, G. ligulata, G. wrayii, G. brang, S. grande, B. heterostachya, and B. vulgaris cv. vittata, respectively; $\mathrm{k}$ through $\mathrm{m}$ ) type IV vascular bundle: $B$. vulgaris, $B$. blumeana, and $D$. asper, respectively 
The fibre morphology is shown in Table 2. The results showed that fibre morphology varied among the species. From the 13 species, G. thoii and G. ligulata had the longest fibres, which were $4,070 \mu \mathrm{m}$ and 3,930 $\mu \mathrm{m}$, respectively. The results indicate that the mean value for fibre length of the 13 bamboo species ranged from 2,330 $\mu \mathrm{m}$ to $4,070 \mu \mathrm{m}$. The average length of bamboo fibre is longer than Eucalyptus spp., $568 \mu \mathrm{m}$ to 1,140 $\mu \mathrm{m}$, (Gominho et al. 2014; Carrillo et al. 2015) and is equivalent to Pinus spp., 2,300 $\mu \mathrm{m}$ to 3,600 $\mu \mathrm{m}$ (Ataç and Eroğlu 2013; Gulsoy and Ozturk 2015). Therefore, bamboo fibres are classified as long fibres according to the International Society for Wood Anatomy (Wheeler et al. 1989). Longer fibre length will contribute to the higher tearing resistance of paper (Sharma et al. 2011).

As stated by Liese (1998), fibre length is associated with internode length; however, in this study it shows that the fibre length is not correlated with the internode length. The fibre length, width, thickness, and lumen diameter for all of the species studied showed a significant decrease $(\mathrm{P}<0.05)$ from the basal to the top of the culm. Razak et al. (2010) also reported a similar trend in fibre length and fibre wall thickness in Bambusa vulgaris. According to Liese (1998), the fibres are generally thicker at the basal portion than in the middle and top portion of the bamboo culm.

The highest mean percentage for vascular bundles was observed at the top portion of the bamboo culm, followed by the middle portion, and the lowest was at the basal portion (Table 2). Similar results were obtained by Xing et al. (2015) and Wang et al. (2016) in Bambusa rigida and Dendrocalamus brandisii, respectively. Nordahlia et al. (2011) also reported an increase in vascular bundles moving up the culm in Schizostachyum brachycladum, which was probably related to the decrease in culm wall thickness from the basal to the top of the bamboo culm. Grosser and Liese (1971) and Abd. Latif and Mohd Tamizi (1992) stated that the higher vascular bundles percentage at the top portion is mainly due to the tapering of the bamboo culm towards the top portion.

In terms of Runkel ratio (Fig. 2), G. thoii had the highest mean value, which was 4.53, followed by G. ligulata (4.30) and B. vulgaris (4.25), while the lowest value was obtained from $S$. zollingeri (1.01). Fibre with a Runkel ratio below 1 is classified as fine raw material, and fibre with a Runkel ratio greater than 1 is considered inferior. Fibre with a Runkel ratio equal to 1 is classified as secondary fibre raw material (Wu 1997; Zhan et al. 2015). As shown in Fig. 2, all of the bamboo species had Runkel ratios greater than 1, which indicated they belong to the inferior raw material for papermaking. According to Kiaei et al. (2014), a high Runkel ratio shows that the fiber is stiff and less flexible.

For aspect ratio (Fig. 3), the highest mean value was obtained by $B$. vulgaris (177.15), followed by $B$. vulgaris cv. vittata (176.70) and G. ligulata (174.13), whereas $G$. wrayi had the lowest value of 114.10. The aspect ratio of pulp fibers for papermaking should be above 100, and a larger ratio results in a better fiber for papermaking (Wang et al. 2008; Yang et al. 2008; Wang et al. 2016). All of the bamboo species in this study showed aspect ratios above 100 and longer fibre indicating good suitability for pulp raw material but greater in Runkel ratio. Similar results were obtained by Chandra and Susi (2018), Wang et al. (2016), Zhan et al. (2015), and Sharma et al. (2011), where they also found the aspect ratios were above 100, there were longer fibres, but the Runkel ratio was greater than 1. However, Chandra and Susi (2018) suggested the use of more chemicals during the cooking process to enable this fibre to be used efficiently. 




Fig. 2. The Runkel ratio of the 13 Malaysian bamboo fibres

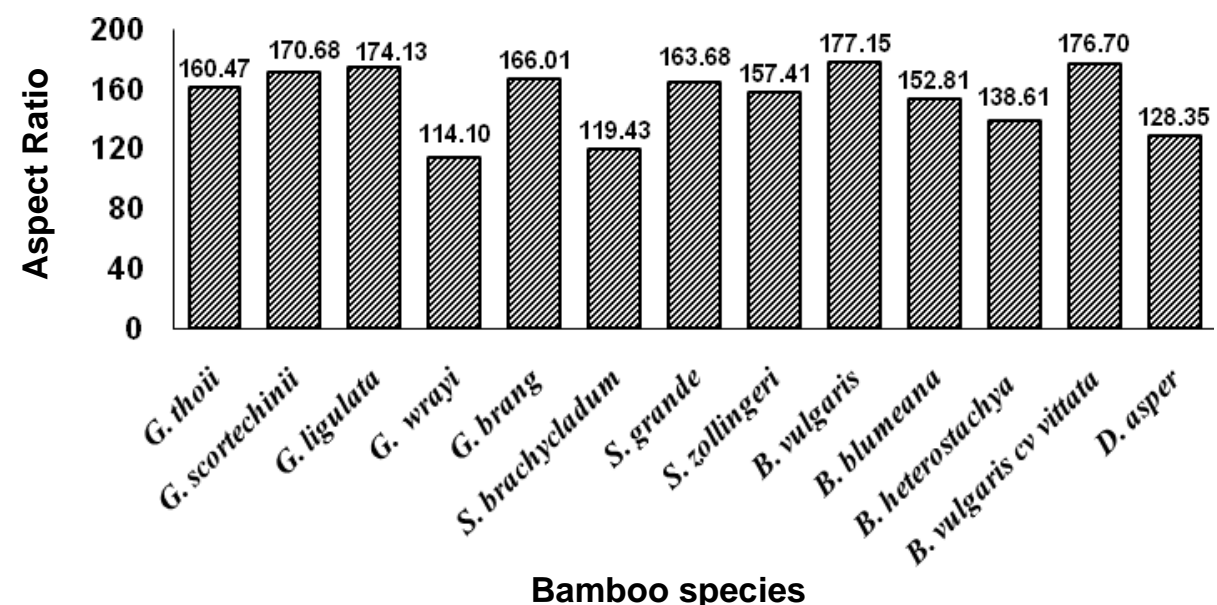

Fig. 3. The aspect ratio of the 13 Malaysian bamboo fibres

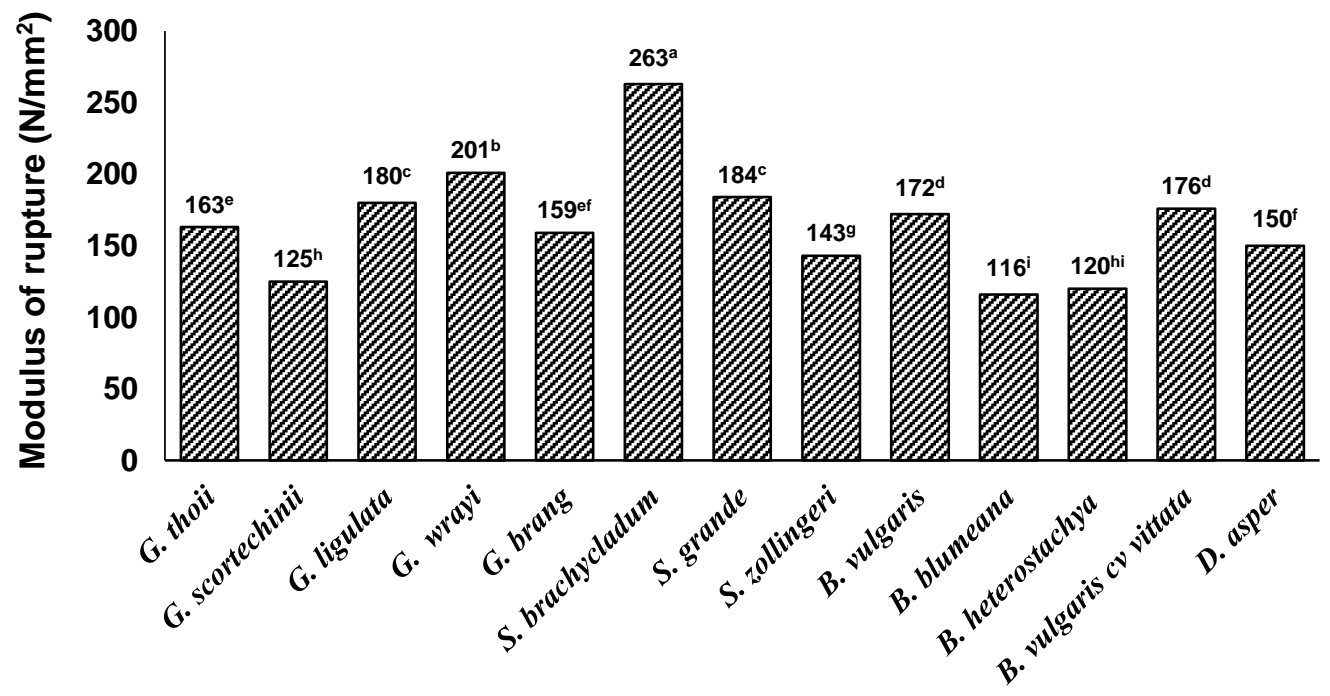

Bamboo species

Fig. 4. Modulus of rupture for the 13 Malaysian bamboos 


\section{Density, Shrinkage, and Mechanical Properties}

Table 3 presents the density and shrinkage properties. Figures 4 and 5 show mechanical properties that include the MOR and MOE of the 13 common bamboo species in Malaysia.

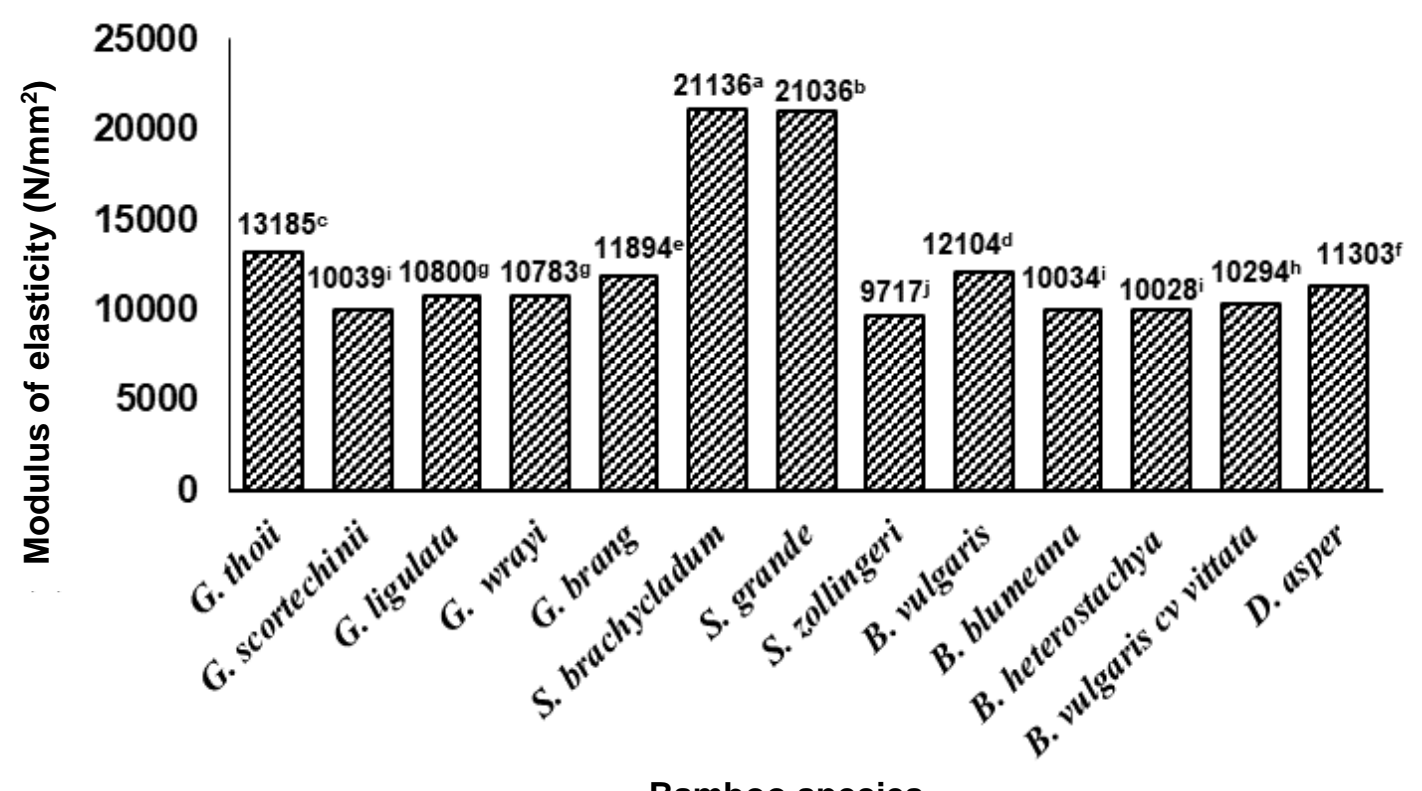

Fig. 5. Modulus of elasticity for the 13 Malaysian bamboos

Among the 13 species, G. thoii showed the highest density which was $751 \mathrm{~kg} / \mathrm{m}^{3}$ compared to the other species. Whilst $S$. brachycladum and $G$. wrayii showed the highest MOR which was $263 \mathrm{~N} / \mathrm{mm}^{2}$ and $201 \mathrm{~N} / \mathrm{mm}^{2}$ respectively. In contrast, S. brachycladum and $S$. grande showed the highest MOE which was $21,100 \mathrm{~N} / \mathrm{mm}^{2}$ and $21,000 \mathrm{~N} / \mathrm{mm}^{2}$, respectively.

Based on this present study, G. scortechinii, G. thoii, and Dendrocalamus asper have potential for structural application since these species have higher density, MOR, and thicker culm walls, but exhibit slightly lower MOE. S. zollingeri exhibited the lowest density (355 $\mathrm{kg} / \mathrm{m}^{3}$ ), which is suitable for general utility purposes, crafts, and decorative panels. Detail usage of each species based on density, MOR, and MOE are tabulated in Table 1.

The results showed that the density increased from the basal towards the top of the bamboo culm for all of the species studied (Table 3). Increases in density values from the basal to the top of the bamboo culm were also reported in Dendrocalamus pendulus, D. asper, Gigantochloa levis, G. scortechinii (Zakikhani et al. 2017), and D. strictus (Bhonde et al. 2014). According to Liese (1987), Abd. Latif and Mohd Tamizi (1992), and Wang et al. (2016), this trend may be associated with the higher value of vascular bundles, coupled with the increase in silica content from basal to the top. Correal and Arbelaez (2010) also mentioned that a high amount of schlerenchyma fibers at the top portion can also contribute to the high density at the top portion of the bamboo culm. The results for radial, longitudinal, and tangential shrinkage from green to oven-dry conditions are presented in Table 3 . It can be seen that the shrinkage value decreased from the basal to the top of the bamboo culm. According to Anwar et al. (2005), the basal portion shrinks more than the other bamboo culm portions probably due to the presence of higher initial moisture content and lower number of vascular bundles. 
Table 1. Physical Characteristics, Density, MOR, MOE, and Uses of 13 Species of Commercial Malaysian Bamboos

\begin{tabular}{|c|c|c|c|c|c|c|c|c|}
\hline Species & Local Name & $\begin{array}{c}\text { Culm } \\
\text { Height } \\
\text { (m) }\end{array}$ & $\begin{array}{l}\text { Internode } \\
\text { Length } \\
\text { (cm) }\end{array}$ & $\begin{array}{c}\text { Culm Wall } \\
\text { Thickness } \\
(\mathrm{mm})\end{array}$ & $\begin{array}{l}\text { Density } \\
\mathrm{Kg} / \mathrm{m}^{3}\end{array}$ & $\begin{array}{c}\text { MOR } \\
\underset{2}{\mathrm{~N} / \mathrm{mm}}\end{array}$ & $\begin{array}{c}\mathrm{MOE} \\
\mathrm{N} / \mathrm{mm}^{2}\end{array}$ & Uses \\
\hline Gigantochloa thoii & Buluh beting & 21 & 35 & 12 & 751 & 163 & 13,185 & Furniture, parquet, structures \\
\hline Gigantochloa scortechinii & Buluh semantan & 21 & 42 & 10 & 641 & 125 & 10,039 & Furniture, parquet, structures \\
\hline Gigantochloa ligulata & Buluh tumpat & 18 & 37 & 12 & 442 & 180 & 10,800 & $\begin{array}{l}\text { Furniture component, basketry, } \\
\text { crafts }\end{array}$ \\
\hline Gigantochloa wrayi & Buluh beti & 18 & 38 & 12 & 628 & 201 & 10,783 & Furniture, blinds, crafts \\
\hline Gigantochloa brang & Buluh brang & 19 & 40 & 14 & 536 & 159 & 11,894 & Furniture, blinds, crafts \\
\hline Schizostachyum brachycladum & Buluh lemang & 21 & 53 & 5 & 588 & 263 & 21,136 & Crafts, cooking vessels \\
\hline Schizostachyum grande & Buluh semeliang & 32 & 65 & 6 & 633 & 184 & 21,036 & Crafts, blinds \\
\hline Schizostachyum zollingeri & Buluh nipis & 22 & 55 & 4 & 355 & 143 & 9,717 & Crafts, basketry, cooking vessels \\
\hline Bambusa vulgaris & Buluh minyak & 16 & 33 & 9 & 610 & 172 & 12,104 & Furniture, parquet, blinds \\
\hline Bambusa blumeana & Buluh duri & 16 & 32 & 11 & 478 & 116 & 10,034 & Furniture, parquet, crafts \\
\hline Bambusa heterostachya & Buluh galah & 20 & 41 & 9 & 531 & 120 & 10,028 & Furniture, parquet, crafts, blinds \\
\hline Bambusa vulgaris cv vittata & Buluh gading & 30 & 33 & 11 & 546 & 176 & 10,294 & Furniture, parquet, crafts \\
\hline Dendrocalamus asper & Buluh betong & 20 & 37 & 16 & 559 & 150 & 11,303 & Furniture, parquet, structures \\
\hline
\end{tabular}

Table 2. Fibre Morphology Along the Culm Height of 13 Commercial Malaysian Bamboos

\begin{tabular}{|c|c|c|c|c|c|c|}
\hline Species & Height Level & $\begin{array}{l}\text { Fibre Length } \\
(\mu \mathrm{m})\end{array}$ & $\begin{array}{l}\text { Fibre Diameter } \\
\qquad(\mu \mathrm{m})\end{array}$ & $\begin{array}{l}\text { Fibre Lumen Diameter } \\
(\mu \mathrm{m})\end{array}$ & $\begin{array}{c}\text { Fibre Wall } \\
\text { Thickness }(\mu \mathrm{m})\end{array}$ & $\begin{array}{c}\text { Frequency of Vascular } \\
\text { Bundle }\left(\mathrm{mm}^{-2}\right)\end{array}$ \\
\hline \multirow{5}{*}{ G. thoii } & Basal & $4,478^{a}$ & $28.9^{a}$ & $6.1^{\mathrm{a}}$ & $14.1^{\mathrm{a}}$ & $15^{c}$ \\
\hline & Middle & $3,900^{b}$ & $25.5^{b}$ & $6.0^{\mathrm{a}}$ & $12.8^{b}$ & $17^{\mathrm{b}}$ \\
\hline & Top & $3,835^{c}$ & $22.1^{c}$ & $4.3^{b}$ & $10.1^{c}$ & $23^{a}$ \\
\hline & \multirow[b]{2}{*}{ Mean } & 4,071 & 25.5 & 5.0 & 12.2 & 18 \\
\hline & & $(3,099$ to 5,043$)$ & (20.5 to 30.5 ) & (2 to 8$)$ & (9 to 15$)$ & (16 to 24$)$ \\
\hline \multirow{3}{*}{ G. scortechinii } & Basal & $2,488^{a}$ & $17.0^{\mathrm{a}}$ & $4.1^{\mathrm{a}}$ & $6.8^{a}$ & $13^{b}$ \\
\hline & Middle & $2,310^{b}$ & $14.8^{b}$ & $3.2^{b}$ & $5.4^{b}$ & $14^{b}$ \\
\hline & Top & $2,180^{c}$ & $10.4^{c}$ & $2.2^{c}$ & $4.3^{c}$ & $21^{a}$ \\
\hline
\end{tabular}




\begin{tabular}{|c|c|c|c|c|c|c|}
\hline & \multirow[b]{2}{*}{ Mean } & 2,326 & 14.1 & 3.2 & 5.5 & 16 \\
\hline & & $(1,753$ to 2,899$)$ & (10.0 to 19.1 ) & (1.3 to 5.1$)$ & (3.4 to 7.5 ) & (6 to 26) \\
\hline \multirow[b]{5}{*}{ G. ligulata } & Basal & $4,146^{a}$ & $22.9^{a}$ & $4.7^{\mathrm{a}}$ & $9.7^{\mathrm{a}}$ & $10^{c}$ \\
\hline & Middle & $3,885^{b}$ & $22.1^{\mathrm{a}}$ & $4.7^{\mathrm{a}}$ & $9.5^{a}$ & $13^{b}$ \\
\hline & Top & $3,758^{c}$ & $22.7^{a}$ & $3.6^{b}$ & $8.5^{b}$ & $16^{\mathrm{a}}$ \\
\hline & \multirow[b]{2}{*}{ Mean } & 3,930 & 22.6 & 4.3 & 9.2 & 13 \\
\hline & & $(3,216$ to 4,643$)$ & (18.5 to 26.6) & (1.6 to 7.0$)$ & (7.5 to 10.8$)$ & $(10$ to 16$)$ \\
\hline \multirow{5}{*}{ G. wrayi } & Basal & 3,040 a & $25.8^{a}$ & $14.1^{\mathrm{a}}$ & $9.0^{\mathrm{a}}$ & $10^{c}$ \\
\hline & Middle & $2,953^{b}$ & $24.0^{b}$ & $10.0^{b}$ & $6.1^{b}$ & $12 \mathrm{~b}$ \\
\hline & Top & $2,262^{c}$ & $22.3^{c}$ & $5.0^{c}$ & $6.0^{b}$ & $15^{a}$ \\
\hline & \multirow[b]{2}{*}{ Mean } & 2,753 & 24.0 & 10.3 & 7.0 & 12 \\
\hline & & $(2,257$ to 3,248$)$ & (20.5 to 27.5) & (4.1 to 15.6$)$ & (4.4 to 9.6$)$ & (9 to 15) \\
\hline \multirow{5}{*}{ G. brang } & Basal & $3,863^{a}$ & $24.2^{\mathrm{a}}$ & $9.7^{\mathrm{a}}$ & $8.6^{a}$ & $6^{c}$ \\
\hline & Middle & $3,435^{b}$ & $22.1^{b}$ & $4.0^{b}$ & $7.5^{b}$ & $7^{b}$ \\
\hline & Top & $3,330^{c}$ & $18.2^{c}$ & $3.7^{c}$ & $7.1^{\mathrm{b}}$ & $9^{a}$ \\
\hline & \multirow[b]{2}{*}{ Mean } & 3,543 & 21.4 & 6.0 & 7.7 & 7 \\
\hline & & $(2,895$ to 4,190$)$ & (15.0 to 28.0 ) & (5.0 to 11.0$)$ & (4.0 to 11.0$)$ & (5 to 10$)$ \\
\hline \multirow{5}{*}{ S. brachycladum } & Basal & $3,195^{a}$ & $23.0^{a}$ & $6.4^{b}$ & $9.0^{\mathrm{a}}$ & $14^{b}$ \\
\hline & Middle & $2,758^{b}$ & $22.3^{b}$ & $6.9 \mathrm{a}$ & $8.2^{b}$ & $14^{b}$ \\
\hline & Top & $2,566^{c}$ & $21.5^{c}$ & $6.0^{b}$ & $6.5^{c}$ & $16^{a}$ \\
\hline & \multirow[b]{2}{*}{ Mean } & 2,840 & 22.2 & 6.4 & 7.9 & 15 \\
\hline & & $(2,638$ to 3,552$)$ & (18.0 to 26.0$)$ & (4.0 to 8.4$)$ & $(6.0$ to 10.0$)$ & (8 to 22) \\
\hline \multirow{5}{*}{ S. grande } & Basal & 2,849 a & $16.0^{a}$ & $3.4^{\mathrm{a}}$ & $7.0^{\mathrm{a}}$ & $10^{c}$ \\
\hline & Middle & $2,262^{b}$ & $14.8^{b}$ & $3.3^{a}$ & $6.5^{a}$ & $12^{b}$ \\
\hline & Top & $2,242^{b}$ & $14.0^{b}$ & $3.0^{a}$ & $5.0^{b}$ & $15^{a}$ \\
\hline & \multirow{2}{*}{ Mean } & 2,451 & 15.0 & 3.1 & 6.1 & 12 \\
\hline & & $(2,105$ to 2,900$)$ & (12.0 to 18.0$)$ & (2.4 to 5.8$)$ & (4.1 to 8.8$)$ & (7 to 19$)$ \\
\hline \multirow{3}{*}{ S. zollingeri } & Basal & $2,723^{a}$ & $19.2^{a}$ & $12.8^{a}$ & $3.6^{a}$ & $8^{c}$ \\
\hline & Middle & $2,285^{b}$ & $15.1^{\mathrm{b}}$ & $7.3^{b}$ & $3.3^{a}$ & $10^{b}$ \\
\hline & Top & $1,970^{c}$ & $11.0^{c}$ & $4.2^{c}$ & $3.3^{a}$ & $12^{a}$ \\
\hline
\end{tabular}




\begin{tabular}{|c|c|c|c|c|c|c|}
\hline & Mean & $\begin{array}{c}2,326 \\
(1,850 \text { to } 2,955)\end{array}$ & $\begin{array}{c}14.8 \\
(10.7 \text { to } 19.9)\end{array}$ & $\begin{array}{c}8.1 \\
(2.9 \text { to } 13.2)\end{array}$ & $\begin{array}{c}3.3 \\
(2.0 \text { to } 4.8)\end{array}$ & $\begin{array}{c}10 \\
\text { (8 to } 12) \\
\end{array}$ \\
\hline \multirow{5}{*}{ B. vulgaris } & Basal & $2,753^{a}$ & $13.3^{b}$ & $3.3^{a}$ & $9.1^{\mathrm{a}}$ & $9^{b}$ \\
\hline & Middle & $2,486^{b}$ & $14.3^{a}$ & $3.7^{a}$ & $7.0^{b}$ & $12^{a}$ \\
\hline & Top & $2,244^{c}$ & $14.9^{a}$ & $3.6^{a}$ & $5.7^{c}$ & $13^{a}$ \\
\hline & \multirow[b]{2}{*}{ Mean } & 2,494 & 14.1 & 3.5 & 7.1 & 11 \\
\hline & & $(1,825$ to 3,159$)$ & (9.5 to 18.8$)$ & (1.4 to 5.6$)$ & (3.4 to 9.5 ) & (8 to 14) \\
\hline \multirow{5}{*}{ B. blumeana } & Basal & $3,438^{a}$ & $20.3^{a}$ & $10.4^{a}$ & $7.2^{\mathrm{a}}$ & $10^{c}$ \\
\hline & Middle & $2,773^{b}$ & $18.5^{\mathrm{b}}$ & $7.1^{b}$ & $5.2^{b}$ & $15^{b}$ \\
\hline & Top & $2,505^{c}$ & $18.0^{b}$ & $5.5^{c}$ & $4.7^{c}$ & $18^{a}$ \\
\hline & \multirow[b]{2}{*}{ Mean } & 2,905 & 18.9 & 7.6 & 5.7 & 14 \\
\hline & & $(2,382$ to 3,458$)$ & (14.3 to 23.5 ) & (3.1 to 12.1 ) & (3.8 to 7.5 ) & (10 to 20$)$ \\
\hline \multirow{5}{*}{ B. heterostachya } & Basal & $4,022^{a}$ & $28.1^{\mathrm{a}}$ & $7.2^{\mathrm{a}}$ & $12.0^{a}$ & $10^{c}$ \\
\hline & Middle & $3,757^{b}$ & $27.0^{b}$ & $6.0^{b}$ & $11.6^{\mathrm{a}}$ & $15^{b}$ \\
\hline & Top & $3,512^{c}$ & $25.4^{c}$ & $4.4^{c}$ & $8.0^{b}$ & $17^{a}$ \\
\hline & \multirow[b]{2}{*}{ Mean } & 3,764 & 26.8 & 5.8 & 10.5 & 14 \\
\hline & & $(3,180$ to 4,148$)$ & (23.0 to 29.1) & (4.0 to 10.2$)$ & (7.3 to 13.0$)$ & (9 to 18 ) \\
\hline \multirow{5}{*}{ B. vulgaris cv. vittata } & Basal & $4,130^{a}$ & $23.8^{a}$ & $8.8^{a}$ & $7.8^{a}$ & $9^{c}$ \\
\hline & Middle & $3,710^{b}$ & $20.4^{b}$ & $7.2^{b}$ & $6.1^{\mathrm{b}}$ & $12^{b}$ \\
\hline & Top & $2,935^{c}$ & $16.8^{c}$ & $5.0^{c}$ & $5.0^{c}$ & $17^{a}$ \\
\hline & \multirow[b]{2}{*}{ Mean } & 3,592 & 20.3 & 6.9 & 6.3 & 13 \\
\hline & & $(2,826$ to 4,158$)$ & (16.0 to 24.1 ) & (4.2 to 10.7 ) & (4.1 to 8.5 ) & (8 to 19) \\
\hline \multirow{5}{*}{ D. asper } & Basal & $3,460^{a}$ & $25.0^{a}$ & $8.0^{a}$ & $9.7^{\mathrm{a}}$ & $10^{c}$ \\
\hline & Middle & $2,920^{b}$ & $24.5^{\mathrm{a}}$ & $5.8^{b}$ & $8.3^{b}$ & $12^{b}$ \\
\hline & Top & $2,613^{c}$ & $20.5^{b}$ & $4.5^{c}$ & $8.0^{b}$ & $16^{a}$ \\
\hline & \multirow[b]{2}{*}{ Mean } & 2,998 & 23.3 & 6.1 & 8.6 & 13 \\
\hline & & $(2,261$ to 3,734$)$ & (19.9 to 26.8 ) & (2.7 to 9.5 ) & (7.2 to 10.1$)$ & (10 to 16$)$ \\
\hline
\end{tabular}

Values in parentheses are standard deviations. Cell values differing by a letter in the superscript in each column are significantly different at the 0.05 probability level. 
Table 3. Density, Shrinkage, MOR, and MOE Along the Culm Height of 13 Commercial Malaysian Bamboos

\begin{tabular}{|c|c|c|c|c|c|c|c|}
\hline Species & Height Level & Density $\left(\mathrm{kg} / \mathrm{m}^{3}\right)$ & \multicolumn{3}{|c|}{ Shrinkage From Green to Oven Dry (\%) } & $\operatorname{MOR}\left(\mathrm{N} / \mathrm{mm}^{2}\right)$ & $\operatorname{MOE}\left(\mathrm{N} / \mathrm{mm}^{2}\right)$ \\
\hline \multirow{4}{*}{ G. thoii } & Basal & $700^{c}$ & $7.71^{\mathrm{a}}$ & $1.88^{\mathrm{a}}$ & $13.04^{\mathrm{a}}$ & $151^{c}$ & $11,808^{c}$ \\
\hline & Middle & $751^{b}$ & $7.03^{b}$ & $1.52^{b}$ & $12.55^{b}$ & $161^{\mathrm{b}}$ & $13,248^{b}$ \\
\hline & \multirow[b]{2}{*}{ Mean } & 751 & 7.14 & 1.58 & 12.12 & 163 & 13,185 \\
\hline & & (649 to 853 ) & (5.02 to 8.89$)$ & $(0.73$ to 2.81$)$ & (8.03 to 13.72) & (130 to 196$)$ & $(10,066$ to 16,304$)$ \\
\hline \multirow{3}{*}{ G. scortechinii } & Basal & $599^{c}$ & $8.58^{a}$ & $0.70^{\mathrm{a}}$ & $11.58^{a}$ & $122^{b}$ & $9,243^{c}$ \\
\hline & \multirow{2}{*}{ Mean } & 641 & 7.73 & 0.56 & 9.77 & 125 & 10,039 \\
\hline & & (573 to 709$)$ & (5.51 to 9.94$)$ & (0.05 to 1.12) & (5.75 to 13.78$)$ & (105 to 146$)$ & $(8,043$ to 12,034$)$ \\
\hline \multirow{4}{*}{ G. ligulata } & Basal & $377^{c}$ & $3.57^{a}$ & $0.32^{a}$ & $7.93^{a}$ & $170^{c}$ & $9,788^{c}$ \\
\hline & Middle & $455^{b}$ & $2.54^{b}$ & $0.26^{b}$ & $7.64^{\mathrm{a}}$ & $180^{b}$ & $10,900^{b}$ \\
\hline & Top & $494^{a}$ & $2.28^{c}$ & $0.27^{b}$ & $6.75^{b}$ & $190^{a}$ & $11,712^{\mathrm{a}}$ \\
\hline & Mean & 442 & 2.80 & 0.28 & 7.42 & 180 & 10,800 \\
\hline \multirow{2}{*}{ G. wrayi } & \multirow{2}{*}{ Mean } & 628 & 2.88 & 0.53 & 3.43 & 201 & 10,783 \\
\hline & & (591 to 666 ) & (1.09 to 4.68$)$ & (0.02 to 1.08) & (1.78 to 5.09$)$ & (179 to 219 ) & $(6,200$ to 13,945$)$ \\
\hline \multirow{5}{*}{ G. brang } & Basal & $475^{c}$ & $7.56^{a}$ & 0.39 a & $8.43^{a}$ & $142^{c}$ & $8,833^{c}$ \\
\hline & Middle & $539^{b}$ & $6.54^{b}$ & $0.27^{b}$ & $8.15^{b}$ & $163^{b}$ & $13,223^{b}$ \\
\hline & Top & $593^{a}$ & $6.49^{b}$ & $0.27^{b}$ & $7.06^{c}$ & $171^{\mathrm{a}}$ & $13,626^{a}$ \\
\hline & \multirow[b]{2}{*}{ Mean } & 536 & 6.86 & 0.31 & 7.90 & 159 & 11,894 \\
\hline & & (479 to 593 ) & (6.06 to 7.67$)$ & $(0.01$ to 0.61$)$ & (6.32 to 9.50) & (138 to 180$)$ & $(8,529$ to 14,859$)$ \\
\hline \multirow{2}{*}{ S. brachycladum } & Basal & $551^{c}$ & $8.14^{a}$ & $0.10^{c}$ & $10.80^{a}$ & $207^{c}$ & $15,817^{c}$ \\
\hline & Middle & $599 \mathrm{~b}$ & $5.51^{b}$ & $0.40^{a}$ & $7.44^{b}$ & $220^{b}$ & $21,540^{b}$ \\
\hline
\end{tabular}




\begin{tabular}{|c|c|c|c|c|c|c|c|}
\hline & Top & $620^{a}$ & $3.74^{c}$ & $0.31^{b}$ & $6.34^{c}$ & $363^{a}$ & $26,051^{a}$ \\
\hline & & 588 & 5.79 & 0.27 & 8.20 & 263 & 21,136 \\
\hline & Mean & (526 to 652) & (3.14 to 8.30) & (0.06 to 0.68$)$ & (4.46 to 11.00) & (201 to 370$)$ & $(15,7062$ to 6,250$)$ \\
\hline \multirow{5}{*}{ S. grande } & Basal & $605^{c}$ & $10.44^{a}$ & $0.68^{a}$ & $13.14^{\mathrm{a}}$ & $155^{c}$ & $14,655^{c}$ \\
\hline & Middle & $620^{b}$ & $6.64^{b}$ & $0.50^{b}$ & $6.76^{b}$ & $175^{b}$ & $22,401^{b}$ \\
\hline & Top & $674^{a}$ & $6.44^{c}$ & $0.46^{c}$ & $6.45^{c}$ & $222^{a}$ & 26,051 a \\
\hline & \multirow[b]{2}{*}{ Mean } & 633 & 7.84 & 0.55 & 8.78 & 184 & 21,036 \\
\hline & & (520 to 745$)$ & (4.28 to 11.45$)$ & (0.07 to 1.02$)$ & (3.83 to 13.64) & (139 to 225) & $(8,996$ to 32,654$)$ \\
\hline \multirow{5}{*}{ S. zollingeri } & Basal & $324^{c}$ & 9.59 a & $0.54^{a}$ & $14.60^{a}$ & $131^{\mathrm{b}}$ & $9,132^{\mathrm{c}}$ \\
\hline & Middle & $368^{b}$ & $8.60^{b}$ & $0.29 \mathrm{~b}$ & $11.78^{c}$ & $137^{b}$ & $9,435^{b}$ \\
\hline & Top & $372^{a}$ & $6.09^{c}$ & $0.27^{b}$ & $12.54^{b}$ & $161^{\mathrm{a}}$ & $10,585^{a}$ \\
\hline & \multirow{2}{*}{ Mean } & 355 & 8.09 & 0.36 & 12.99 & 143 & 9,717 \\
\hline & & (315 to 394$)$ & (5.74 to 10.45$)$ & $(0.02$ to 0.72$)$ & (7.30 to 18.67$)$ & (127 to 162$)$ & $(8,869$ to 10,600$)$ \\
\hline \multirow{5}{*}{ B. vulgaris } & Basal & $589^{c}$ & $6.41^{a}$ & $2.90^{a}$ & $9.21^{a}$ & $153^{c}$ & $9,570^{c}$ \\
\hline & Middle & $604^{b}$ & $5.86^{b}$ & $1.52 \mathrm{~b}$ & $8.33^{b}$ & $174^{b}$ & $11,767^{b}$ \\
\hline & Top & $637^{a}$ & $5.45^{c}$ & $1.25^{c}$ & $7.87^{c}$ & $190^{a}$ & $14,974^{a}$ \\
\hline & \multirow[b]{2}{*}{ Mean } & 610 & 5.91 & 1.90 & 8.47 & 172 & 12,104 \\
\hline & & (564 to 656) & (4.14 to 7.68$)$ & (0.54 to 2.95$)$ & (5.26 to 10.90$)$ & (144 to 200) & $(8,215$ to 15,992$)$ \\
\hline \multirow{5}{*}{ B. blumeana } & Basal & $456^{c}$ & $7.23^{a}$ & $0.96^{a}$ & $13.04^{a}$ & $110^{b}$ & $9,125^{c}$ \\
\hline & Middle & $478^{b}$ & $6.23^{b}$ & $0.74^{b}$ & $12.40^{b}$ & $111^{b}$ & $10,046^{b}$ \\
\hline & Top & $501^{a}$ & $5.82^{c}$ & $0.28^{c}$ & $9.76^{c}$ & $128^{a}$ & $10,931^{a}$ \\
\hline & \multirow{2}{*}{ Mean } & 478 & 6.40 & 0.66 & 11.70 & 116 & 10,034 \\
\hline & & (453 to 503 ) & (5.04 to 7.76$)$ & (0.10 to 1.41$)$ & (9.37 to 14.01) & (102 to 130$)$ & $(9,068$ to 10,999$)$ \\
\hline \multirow{5}{*}{ B. heterostachya } & Basal & $461^{b}$ & $5.73^{a}$ & $1.21^{b}$ & 12.93 a & $105^{c}$ & $9,060^{c}$ \\
\hline & Middle & $465^{b}$ & $4.92^{b}$ & $1.98^{a}$ & $11.86^{b}$ & $122^{b}$ & $10,210^{b}$ \\
\hline & Top & $664^{a}$ & $3.43^{c}$ & $1.26^{b}$ & $8.95^{c}$ & $133^{a}$ & $10,814^{a}$ \\
\hline & \multirow[b]{2}{*}{ Mean } & 531 & 4.70 & 1.49 & 11.23 & 120 & 10,028 \\
\hline & & (424 to 670 ) & (3.38 to 6.08) & (0.56 to 2.42$)$ & (7.75 to 14.71) & (102 to 140$)$ & $(9,058$ to 10,850$)$ \\
\hline \multirow{2}{*}{ B. vulgaris cv vittata } & Basal & $523^{c}$ & $4.37^{a}$ & $0.44^{a}$ & $7.43^{a}$ & $161^{c}$ & $7,216^{c}$ \\
\hline & Middle & $540^{b}$ & $3.35^{b}$ & $0.31^{b}$ & $6.44^{b}$ & $176^{b}$ & $10,905^{b}$ \\
\hline
\end{tabular}




\section{bioresources.com}

\begin{tabular}{|c|c|c|c|c|c|c|c|}
\hline & Top & $575^{a}$ & $3.01^{c}$ & $0.35^{b}$ & $4.63^{c}$ & $189^{a}$ & $12,761^{a}$ \\
\hline & \multirow[b]{2}{*}{ Mean } & 546 & 3.58 & 0.37 & 6.17 & 176 & 10,294 \\
\hline & & (489 to 603 ) & (1.69 to 5.47$)$ & (0.22 to 0.51$)$ & (4.10 to 8.23) & (1452 to 06 ) & $(7,200$ to 13,374$)$ \\
\hline \multirow{5}{*}{ D. asper } & Basal & $486^{c}$ & 6.29 a & $0.48^{a}$ & $8.30^{a}$ & $131^{c}$ & $9,953^{c}$ \\
\hline & Middle & $573^{b}$ & $4.50^{b}$ & $0.36^{b}$ & $7.07^{b}$ & $145^{b}$ & $10,583 \mathrm{~b}$ \\
\hline & Top & $617^{a}$ & $2.10^{c}$ & $0.36^{b}$ & $5.87^{c}$ & $175^{a}$ & $13,374^{a}$ \\
\hline & \multirow[b]{2}{*}{ Mean } & 559 & 4.30 & 0.40 & 7.12 & 150 & 11,303 \\
\hline & & (471 to 646 ) & (2.06 to 6.55$)$ & (0.15 to 0.64$)$ & (5.70 to 8.54$)$ & (127 to 180$)$ & $(9,630$ to 13,500$)$ \\
\hline
\end{tabular}

Values in parentheses are standard deviations. Cell values differing by a letter in the superscript in each column are significantly different at the 0.05

probability level. $T=$ Tangential, $L=$ Longitudinal, $R=$ Radial, MOR = Modulus of rupture, and MOE = Modulus of elasticity 
Increases in MOR and MOE (Table 3) were observed along the culm height in all 13 species studied. This was consistent with results obtained in Gigantochloa scortechinii (Hamdan et al. 2009; Shahril and Mansur 2009), Dendrocalamus latiflorus, Dendrocalamus merrillanus, Bambusa vulgaris (Leoncio 2017), and Dendrocalamus strictus (Bhonde et al. 2014). The increasing tendency of the MOR and MOE in all species studied was accompanied by the higher amount of vascular bundles along the culm height (Table 2). Moreover, the increasing mean density towards the top portion (Table 3) also influenced the increase in MOR and MOE. This is further supported by the findings of Correal and Arbelaez (2010) and Archila-Santos et al. (2014), who also stated that the increase in MOR and MOE was influenced by the density and percentage of vascular bundle.

\section{CONCLUSIONS}

1. The anatomical, physical, and mechanical properties of 13 commercial Malaysian bamboo species were successfully evaluated and the properties were different between the species. This information is important to assess bamboo suitability for various end products. From the 13 species that have been studied, G. thoii and G. ligulata had the longest fibres, which were 4,071 $\mu \mathrm{m}$ and 3,930 $\mu \mathrm{m}$, respectively.

2. G. thoii showed the highest density, which was $751 \mathrm{~kg} / \mathrm{m}^{3}$ compared to the other species. Whilst $S$. brachycladum and $G$. wrayii showed the highest MOR, which was $263 \mathrm{~N} / \mathrm{mm}^{2}$ and $201 \mathrm{~N} / \mathrm{mm}^{2}$, respectively. In contrast, S. brachycladum and S. grande showed the highest MOE, which was $21,136 \mathrm{~N} / \mathrm{mm}^{2}$ and $21,036 \mathrm{~N} / \mathrm{mm}^{2}$, respectively.

3. S. brachycladum and S. zollingeri showed type II vascular bundles with the enlarged fibre sheath at the phloem side. In contrast, G. thoii, G. scortechinii, G. ligulata, G. wrayii, G. brang, S. grande, B. heterostachya, and B. vulgaris cv vittata had type III vascular bundles with one isolated fibre bundle. Alternatively, $B$. vulgaris, $B$. blumeana, and $D$. asper had type IV vascular bundles with a central vascular strand that had small sclerenchyma sheaths, and two isolated fibre strands located at the phloem and protoxylem sides.

4. In terms of Runkel ratio, it was shown that all 13 species had inferior raw material for papermaking where the Runkel ratios were greater than 1 . However, the aspect ratio of the 13 species of bamboo showed good suitability for pulp raw material where the aspect ratios were above 100 .

5. The results obtained in this study demonstrated that fiber morphology and shrinkage from green to oven-dry conditions decreased from the basal to the top of the bamboo culm in all of the species studied. In contrast, the opposite tendency was observed in the percentage of vascular bundles, density, MOR, and MOE.

\section{REFERENCES CITED}

Abasolo, W. P., Fernandez, E. C., and Liese, W. (2005). "Fibre characteristics of Gigantochloa levis and Dendrocalamus asper as influenced by organic fertilizers," Journal of Tropical Forest Science 17(2), 297-305. 
Abd. Latif, M., and Mohd. Tamizi, M. (1992). "Variation in anatomical properties of three Malaysian bamboos from natural stands," Journal of Tropical Forest Science 5(1), 90-96.

Abd. Latif, M., Wan Tarmeze, W. A., and Fauzidah, A. (1990). "Anatomical features and mechanical properties of three Malaysia bamboos," Journal of Tropical Forest Science 2(3), 227-234.

Abd. Razak, O., and Abd. Latif, M. (1995). "Bamboos of Peninsular Malaysia," in: Planting and Utilization of Bamboo in Peninsular Malaysia, Research Phamplet No. 118, O. Abd. Razak, M. Abd. Latif, W. Liese, and H. Norini (eds.), Forest Research Institute Malaysia, Kepong, Kuala Lumpur, Malaysia, pp. 1-17.

Abdullah, A. H. D., Karlina, N., Rahmatiya, W., Mudaim, S., Patimah, and Fajrin A. R. (2017). "Physical and mechanical properties of five Indonesian bamboos," IOP Conference Series: Earth and Environment Science 60, 1-5.

Anonymous (1976). "Indian standard methods of tests for split bamboos," Indian Standards Institution, New Delhi, India.

Anwar, U. M. K., Zaidon, A., Paridah, M. T., and Razak, W. (2004). "The potential of utilising bamboo culm (Gigantochloa scortechinii) in the production of structural plywood," Journal Bamboo and Rattan 3(4), 393-400.

Anwar, U. M. K., Zaidon, A., Hamdan, H., and Mohd. Tamizi, M. (2005a). "Physical and mechanical properties of Gigantochloa scortechinii bamboo splits and strips," Journal of Tropical Forest Science 17(1), 1-12.

Anwar, U. M. K., Paridah, M. T., Hamdan, H., Abd Latif, M., and Zaidon, A. (2005b). "Adhesion and bonding properties of plybamboo manufactured from Gigantochloa scortechinii," American Journal of Applied Sciences (Special Issue), 53-58

Anwar, U. M. K., Paridah, M. T., Hamdan, H., Zaidon, A., Roziela Hanim, A., and Nordahlia, A. S. (2012). "Adhesion and bonding properties of low molecular weight phenol formaldehyde-treated plybamboo," Journal of Tropical Forest Science 24(3), 379-386.

Anwar, U. M. K., Hiziroglu, S., Hamdan, H., and Latif, M. A. (2011). "Effect of outdoor exposure on some properties of resin-treated plybamboo," Industrial Crops and Products 33(1), 140-145.

Archila-Santos, H. F., Ansell, M. P., and Walker, P. (2014). "Elastic properties of thermos-hydro-mechanically modified bamboo (Guadua angustifolia Kunth) measured in tension," Key Engineering Materials 600, 111-120. DOI: 10.4028/www.scientific.net/KEM.600.111.

Ataç, Y., and Eroğlu, H. (2013). "The effects of heartwood and sapwood on kraft pulp properties of Pinus nigra J. F. Arnold and Abies bornmuelleriana Mattf," Turkish Journal of Agriculture and Forestry 37(2), 243-248. DOI: 10.3906/tar-1205-20.

Bhonde, D., Nagarnaik, P. B., Parbat, D. K., and Waghe, U. P. (2014). "Physical and mechanical properties of bamboo (Dendrocalamus strictus)," International Journal of Scientific \& Engineering Research 5(1), 455-459.

Carrillo, I., Graciela, M. A., Valenzuela, S., Mendoca, R. T., and Elissetche, J. P. (2015). "Variations in wood anatomy and fiber biometry of Eucalyptus globulus genotypes with different wood density," Wood Research 60(1), 1-10.

Chandra, A. P., and Susi, S. (2018). "Pembuatan dan karakterisasi dissolving pulp serat panjang dari bambu duri (Bambusa blumeana)," Jurnal Selulosa 8(1), 21-32. 
Correal, J. F., and Arbelaez, C. J. (2010). "Influence of age and height position on Colombian Guadua angustifolia bamboo mechanical properties," Maderas. Ciencia y Tecnología 12(2), 105-113.

Espiloy, Z. B. (1987). "Mechanical properties and anatomical relationship of some Philippines bamboos," in: Proceedings of the 1985 International Workshop on Bamboo, A. N. Rao, G. Dhanarajan, and C. B. Sastry (eds.), The Chinese Academy of Forestry and International Development Research Centre, Hangzhou, China, pp. 257265.

Gnanaharan, R., Janssen, J. J. A., and Arce, O. (1994). Bending Strength of Guadua Bamboo. Comparison of Different Procedures, International Network for Bamboo and Rattan, Working Paper No. 3, New Delhi, India.

Gominho, J., Lopes, C., Lourenço, A., Simões, R. and Pereira, H. (2014). "Eucalyptus globulus stumpwood as a raw material for pulping," BioResources 9(3), 4038-4049. DOI: $10.15376 /$ biores.9.3.4038-4049.

Grosser, D., and Liese, W. (1971). "On the anatomy of Asian bamboos, with special reference to their vascular bundles," Wood Science and Technology 5(4), 290-312.

Gülsoy, S. K., and Ozturk, F. (2015). "Kraft pulping properties of European black pine cone," Maderas. Ciencia y Tecnología 17(4), 875-882. DOI:

10.4067/S0718221X2015005000076

Gülsoy, S. K., Hafizoglu, H., Pekgozlu, A. K., Tumen, İ., Donmez, İ. E., and Sivrikaya, H. (2017). "Fiber properties of axis and scale of eleven different coniferous cones," Industrial Crops and Products 109, 45-52.

Gutu, T. (2013). "A study on the mechanical strength properties of bamboo to enhance its diversification on its utilization," International Journal of Innovative Technology and Exploring Engineering 2(5), 2278-3075.

Hanim, A. R., Zaidon, A., Abood, F., and Anwar, U. M. K. (2010). "Adhesion and bonding characteristics of preservative-treatment bamboo (Gigantochloa scortechinii) laminates," Journal of Applied Science 10(14), 1435-1441.

Hamdan, H., Anwar, U. M. K, Zaidon, A., and Mohd. Tamizi, M. (2009). "Mechanical properties and failure behaviour of Gigantochloa scortechinii," Journal of Tropical Forest Science 21(4), 336-344.

Jamaluddin, K., Abd. Jalil, A., and Abd. Latif, M. (1999). "Properties of urea-and cement bonded from three years old bamboo (Gigantochloa scortechinii)," Journal of Tropical Forest Products 5(1), 39-45.

Kiaei, M., Tajik, M., and Vaysi, R. (2014). "Chemical and biometrical properties of plum wood and its application in pulp and paper production," Maderas. Ciencia y Tecnología 16(3), 313-322.

Krause, J. Q., and Ghavami, K. (2009). "Transversal reinforcement in bamboo culms," in: Proceedings of the $11^{\text {th }}$ International Conference on Non-conventional Materials and Technologies, Bath, UK, pp. 1-288.

Leoncio, M. C. A. (2017). "Comparative mechanical properties of selected bamboo species," International Journal of Precious Engineering Research and Application 2(1), 1-8.

Liese, W. (1985). "Anatomy and properties of bamboo. Recent research on bamboos," in: Proceedings of the 1985 International Bamboo Workshop, Hangzhou, China, pp. 1386. 
Liese, W. (1987). "Anatomy and properties of bamboo," in: Proceedings of the 1986 International Bamboo Workshop, A. N. Rao, G. Dhanarajan, and C. B. Sastry (eds.), Hangzhou, China, pp. 196-208.

Liese, W. (1998). The Anatomy of Bamboo Culms (Report No. 18), International Network for Bamboo and Rattan, Beijing, China.

Nordahlia, A. S., Anwar, U. M. K., Hamdan, H., Abd. Latif, M., and Mahanim, S. M. A. (2011). "Anatomical, physical and strength properties of Shizostachyum brachycladum (buluh lemang)," Journal of Bamboo and Rattan 10(3-4), 111-122.

Razak, W., Hashim, W. S., Wan Tarmeze, W. A., and Mohd. Tamizi, M. (1997). Industri Pembuatan Pepapan Laminasi Buluh [Manufacture of Bamboo Laminate], Forest Research Institute Malaysia, Kepong, Selangor, Malaysia.

Razak, W., Hashim, W. S., Azmy, M., and Janshah, M. (2005). "Energy dispersive X-ray analysis on preservatives treated tropical bamboo species," Journal of Biological Sciences 5(6), 837-841. DOI: 10.3923/jbs.2005.837.841

Razak, W., Mohd. Tamizi, M., Othman, S., Aminuddin, M., Affendy, H., and Izyan, K. (2010). "Anatomical and physical properties of cultivated two- and four-year-old Bambusa vulgaris," Sains Malaysiana 39(4), 571-579.

Razak, W., Murphy, J., and Hashim, W. S. (2002). "SEM observations on decay of Bambusa vulgaris bamboo exposed in tropical soil," Journal of Tropical Forest Products 8(2), 168-178.

Sattar, M. A., Kabir, M. F., and Bhattacharjee, D. K. (1992). "Physical and mechanical properties of six important bamboo species of Bangladesh," in: Proceedings of the International Symposium on Industrial Use of Bamboo, S. Zhu, W. Li, X. Zhang, and Z. Wang (eds.), Beijing, China, pp. 112-117.

Shahril, A. B., and Mansur, A. (2009). "Effects of culm height levels and node presence on mechanical properties and fracture modes of Gigantochloa scortechinii strips loaded in shear parallel to grain," The Journal of the American Bamboo Society 22(1), 41-44.

Sharma, A. K., Dutt, D., Upadhyaya, J. S., and Roy, T. K. (2011). “Anatomical, morphological and chemical characterization of Bambusa tulda, Dendrocalamus hamiltonii, Bambusa balcooa, Malocana baccifera, Bambusa arundinaceae and Eucalyptus tereticornis," BioResources 6(4), 5062-5073. DOI: 10.15376/biores.6.4.5062-5073.

Singh, S., and Mohanty, A. K. (2007). "Wood fiber reinforced bacterial bioplastic composites: Fabrication and performance evaluation," Composites Science and Technology 67(9), 1753-1763.

Tan, T., Rahbar, N., Allameh, S. M., Kwofie, S., Dissmore, D., Ghavami, K., and Soboyejo, W. O. (2011). "Mechanical properties of functionally graded hierarchical bamboo structures," Acta Biomaterialia 7(10), 3796-3803.

Wang, C. M., Wang, J., Wang, W. J., Mu, Q. Y., and Deng, Q. P. (2008). “The property and papermaking performance of the major bamboo species in Yunnan Province," China Pulp \& Paper 27(8), 10-12.

Wang, Y., Hui, Z., Yulong, D., Shuguang, W., and Shuyan, L. (2016). "Variability of anatomical and chemical properties with age and height in Dendrocalamus brandisii," BioResources 11(1), 1202-1213. DOI: 10.15376/biores.11.1.1202-1213

Wheeler, E. A., Baas, P., and Gasson, P. E. (1989). "IAWA list of microscopic features for hardwood identification," IAWA Bulletin 10(3), 219-332. 
Wu, Y. M. (1997). Plant Fibre Chemistry, China Light Industry Press, Beijing, China, pp. 70-74.

Xing, Y. H., Jin, Q. Q., Jiu, L. X., Jian, F. H., Bai, D. Q., and Si, M. C. (2015). "Variation in anatomical characteristics of bamboo, Bambusa rigida," Sains Malaysiana 44(1), 17-23.

Yang, Q., Su, G. R., Duan, Z. B., Wang, Z. L., Hang, L., Sun, Q. X., and Peng, Z. H. (2008). "Fibre characteristics and papermaking feasibility of major sympodial bamboos in Xishuangbanna," Transactions of China Pulp and Paper 23(4), 1-7.

Zaidon, A., Paridah, M. T., Sari, C. K. M., Razak, W., and Yuziah, M. Y. N. (2004). "Bonding characteristics of Gigantochloa scortechinii," Journal of Bamboo and Rattan 3(1), 57-68.

Zakikhani, P., Zahari, R., Sultan, M. T. H., and Dayang, L. M. (2017). "Morphological, mechanical, and physical properties of four bamboo species," BioResources 12(2), 2479-2495. DOI: 10.15376/biores.12.2.2479-2495

Zhan, H., Tang, G., Wang, C., and Wang, S. (2015). "Chemical properties and fibre morphology of Fargesia fungosa at different culm ages and heights," BioResources 10(3), 5666-5676. DOI: 10.15376/biores.10.3.5666-5676

Article submitted: November 7, 2018; Peer review completed: January 19, 2019; Revised version received: March 13, 2019; Accepted: March 14, 2019; Published: March 27, 2019. DOI: 10.15376/biores.14.2.3925-3943 